\title{
REINTERPRETASI KONSEP DHARMA YUDHA DALAM KONTEKS MODERNISASI DAN DOMINASI AGAMA SEMITIK REFLEKSI KRITIS ATAS FENOMENA PEMBELAAN AGAMA
}

Oleh:

Ketut Angga Irawan

(Email: iketutanggairawan@gmail.com)

\begin{abstract}
The concept of holy war has been translated and practiced by followers of Semitik religion in history as an attempt to defend their religion. In Hinduism there is no terms of holy war but there is a concept of dharma yudha. Aim of this journal was to review the concept of dharma yudha in Hindu literature and re-interpret the concept of dharma yudha in the middle of modernization and domination of Semitik religion. Writer performed literature study (research library) to study the form of dharma yudha recorded in Hindu scriptures. Meanwhile, to reinterpret the concept of dharma yudha in the context of modernization and dominance of Semitik religion, writer did interpretivism study with hermeneutic approach. In Hindu manuscripts there are two great stories of dharma yudha it were Ramayana and Mahabharata. The story of battle between Gods and Asuras is also told in puranas. However, unlike religious wars, dharma yuddha does not fight innocent people. In the present, the concept of dharma yudha can no longer be interpreted as war and bloodshed. The concept of dharma yudha can be interpreted as: (1) defend basic human rights, (2) live based on justice and morals, (3) realizing social justice for all humanity. To win dharma and maintaining unity in NKRI, we need an effort to build anti violence culture and eroding suspicion and hostility so that people, especiallu Hindus can be living in harmoony by developing intercomunal groups. It will become a powerful force to dampen any religious conflict that arises in Indonesia
\end{abstract}

Keywords: dharma yudha; Semitik religion; defend religion

\section{PENDAHULUAN}

Agama adalah ajaran yang berasal dari Tuhan atau hasil renungan manusia yang terkandung dalam kitab suci yang turun temurun diwariskan oleh suatu generasi ke generasi dengan tujuan untuk memberi tuntunan dan pedoman hidup bagi manusia agar mencapai kebahagiaan di dunia dan di akhirat yang di dalamnya mencakup unsur kepercayaan kepada kekuatan gaib yang selanjutnya menimbulkan respon emosional dan keyakinan bahwa kebahagiaan hidup tersebut tergantung pada adanya hubungan yang baik dengan kekuatan gaib tersebut (Asir, 2014). Secara normatif agama memang menjadi sebuah energi positif bagi pemeluknya, namun pada kenyataannya 
tidak demikian. Agama juga mampu menjadi energi negatif bagi pemeluknya untuk melakukan kerusakan.

Sejarah mencatat bahwa banyak konflik di sepanjang sejarah yang seolah-olah terjadi untuk tujuan yang religius atau dikenal dengan istilah perang suci. Misalnya saja perang Salib yang mempunyai tujuan untuk merebut kota suci Palestina dari tangan kaum Muslimin. Perang agama di Perancis pada abad keenam belas, antara kelompok Katolik dengan Prostestan Huguenot, perang tiga puluh tahun yang merupakan perang yang terjadi antara kelompok Katolik dengan Prostestan, pada abad ketujuh belas yang terjadi di Jerman (BBC, 2017)

Laporan dari 2018 Minority Rights Group menyatakan bahwa dalam beberapa tahun kebelakang, tingkat kekerasan atas dasar agama semakin meningkat di seluruh dunia (International, 2018). Serangan teroris 11 September, perang berkelanjutan antara orang Yahudi dan Palestina, konflik nasionalis di Balkan, perang etnis di Afrika, mendidihnya konflik antara Pakistan dan India, tindakan terorisme oleh fundamentalis Kristen ekstrim kanan di Amerika Serikat, serangan gas beracun di kereta bawah tanah oleh sekte Aum Shinrikyô di Tokyo, penganiayaan terhadap Falun Gong di Tiongkok adalah sejumlah daftar peristiwa kekerasan paling dramatis yang melibatkan agama.

Beberapa tahun terakhir, jumlah konflik dan bentrok antar agama di Indonesia juga dilaporkan semakin meningkat. Setara Institute mencatat 208 peristiwa pelanggaran kebebasan beragama/berkeyakinan pada 2016 dengan 270 bentuk tindakan. Sebanyak 123 tindakan pelanggaran dilakukan oleh aktor negara dalam bentuk aktif, seperti pernyataan-pernyataan pejabat publik yang provokatif dan mengundang terjadinya kekerasan, dan 17 peristiwa merupakan tindakan pembiaran. Pada 2017, terdapat 155 peristiwa pelanggaran kebebasan beragama/berkeyakinan tercatat dengan 201 bentuk tindakan. Sebanyak 75 tindakan pelanggaran melibatkan aktor negara, yaitu 71 berbentuk tindakan aktif, 3 tindakan by rule, sementara 1 tindakan lainnya merupakan tindakan pembiaran. Sebanyak 126 tindakan dilakukan oleh aktor non-negara dengan pelaku tertinggi adalah kelompok warga, yakni 28 tindakan (Scholastica Gerintya, 2018). Korban dari tindakan kekerasan ini terutama dialami oleh kelompok minoritas termasuk penganut agama Hindu. 
Beberapa ahli menyatakan bahwa perang suci dilakukan untuk mempertahankan eksistensi dan memperluas penyebaran ajaran agama. Namun, di era modern, muncul teori - teori lain yang menjelaskan eratnya hubungan antara agama dengan kekerasan. Cavanaugh berpendapat bahwa bahkan ketika para ekstremis menggunakan teks-teks teologis untuk membenarkan tindakan mereka, kekerasan "agama" sama sekali bukan agama - tetapi lebih merupakan penyimpangan dari ajaran inti. Dawkins percaya bahwa karena agama menjanjian kepastian dan menguduskan martir, mereka seringkali menjadi akar penyebab konflik. Lane menyebut perasaan ancaman yang disebut sebagai "kecemasan sosial xenophobia", muncul ketika ada pengucilan politik dan budaya dan ketidaksetaraan sosial dan ekonomi dan akhirnya dapat meningkat menjadi kekerasan fisik yang ekstrem (Küng, 2005)

Agama Hindu tidak dikenal adanya istilah perang suci, namun ada istilah dharma yudha yang dapat diartikan sebagai perang membela dharma. Perintah dalam kita suci untuk berperang mempunyai nilai intrinsiknya sendiri. Sebagai sebuah nilai intrinsik, dharma yudha menggambarkan tentang spirit, etos yang berorientasi pada kebaikan dan kebenaran yang manifestasinya tidak tunggal. Pandangan bahwa hanya dengan berperang seseorang telah melakukan kewajiban agama merupakan pernyataan yang tidak logis.

Salah satu kisah dharma yudha yang paling besar dalam sejarah Hindu adalah perang antara Pandawa dan Kurawa dalam Mahabharata. Namun, di era modern seperti saat ini, konsep dharma yudha sebagai peperangan yang sebenarnya sudah tidak lagi relevan. Dharma yudha perlu dimaknai kembali sebagai salah satu upaya bagi umat Hindu untuk mempertahankan eksistensi agama Sanatana Dharma di Indonesia.

Penulisan jurnal ini bertujuan untuk mengetahui konsep dharma yudha dalam sastra Hindu dan untuk mengetahui reinterpretasi konsep dharma yudha dalam konteks modernisasi dan dominasi agama Semitik. Dalam jurnal ini penulis melakukan kajian pustaka (library research) untuk mengkaji konsep dharma yudha dalam sastra Hindu. Sementara untuk menginterpretasikan kembali konsep dharma yudha dalam konteks modernisasi dan dominasi agama Semitik, dilakukan pengkajian kefilsafatan interpretivisme dengan pendekatan hermeneutik. 
Penulis merumuskan masalah sebagai berikut: (1) Bagaimanakah konsep dharma yudha yang tercatat dalam sastra Hindu? dan (2) Bagaimanakah reinterpretasi konsep dharma yudha dalam konteks modernisasi dan dominasi agama Semitik?

\section{DHARMA YUDHA DALAM SASTRA HINDU}

Salah satu ajaran dalam agama Hindu adalah Ahimsa. Terdapat salah satu sloka yang dalam Veda yang mengatakan "Ahimsaya paro dharmah" yang artinya "Dharma atau kebajikan tertinggi adalah Ahimsa". Namun, Hindu menyadari perlunya perang demi membela kebenaran. Dharma sastra mengenali dua jenis perang yaitu: Dharma Yuddha (perang membela kebenaran), dan Adharma Yuddha (perang yang tidak benar). Adharma Yuddha juga dikenal sebagai Kutta Yuddha. Penulis India kuno mengajukan beberapa penyebab perang, yang bisa diklasifikasikan dalam empat kategori besar yaitu: keinginan untuk mengamankan kekuatan kerajaan, baik melalui agresi maupun melalui cara Aswameda atau Vajapeya (pengorbanan khusus); menjaga diri; pemeliharaan keseimbangan kekuatan; mempertahankan kekuatan raja dari pembelotan rakyatnya. Pencurian istri juga merupakan penyebab perang. Misalnya, dalam epik Ramayana, penculikan Rahwana terhadap istri Rama adalah alasan untuk melancarkan perang.

Perang dibenarkan dalam ajaran Hindu, bila perang diperjuangkan untuk menegakkan dharma atau melindungi yang lemah dan yang tidak bersalah. Semua dewa Hindu memiliki aspek pejuang tentang mereka dan membawa berbagai jenis senjata. Ketika ditantang oleh Asura (raksasa) mereka berpartisipasi dalam peperangan baik sendiri atau mencari pertolongan dari dewa lain untuk bergabung dengan mereka dalam pertarungan. Epik dan Purana dipenuhi dengan peperangan yang terjadi antara dewa dan setan atau kisah yang paling terkenal adalah peperangan dalam Mahabharata dan Ramayana.

Perang besar melawan adharma digambarkan dalam Mahabharata. Perang ini adalah puncak dari permusuhan yang mendalam antara dua klan kerajaan, Pandawa dan Kurawa. Kurawa secara tidak sah telah merebut harta milik Pandawa. Perang dimulai setelah semua negosiasi oleh Krishna dan yang lainnya gagal untuk mencegahnya dan dengan demikian Pandawa harus dihadapkan dengan dua pilihan yaitu memperjuangkan hak mereka atau menghindari pertempuran dan menerima 
kekalahan demi kedamaian. Tepat sebelum permusuhan dimulai, Arjuna meminta Krishna untuk menempatkan keretanya di antara kedua belah pihak sehingga ia bisa melihat musuhnya dengan baik. Di barisan musuh Arjuna melihat sepupu, kerabat lainnya dan gurunya. Pada momen krusial itu, keterikatan Arjuna terhadap keluarga, sanak saudara dan gurunya menyeruak dan muncul keraguan dalam pikirannya tentang "kebenaran" pertempuran tersebut. Dalam kebingungannya, dia tidak lagi tahu tindakan mana yang harus dilakukannya. Oleh karena itu dia berpaling kepada Krishna untuk memohon bimbingan. Krishna menunjukkan kepadanya bagaimana untuk mengatasi kepribadiannya sendiri dapat melakukan apa yang terbaik untuk dirinya dan bagi masyarakat. Krishna mengajarkan kebijaksanaan spiritual dan sarana untuk mencapai persatuan dengan Tuhan. Tujuh ratus ayat Bhagavad Gita adalah dialog antara Krishna dan Arjuna di medan perang Kurukshetra. Beberapa sloka dalam Bhagavad Gita yang diterjemahkan oleh (Pudja, 2003) yang menekankan pada pentingnya dharma yudha untuk membela dharma adalah:

Sva-darmam api cāvekşya, na vikampitum arhasi, dharmyād dhi yudhhāc chreyo'nyat, ksatriyasya na vidyate (Bhagavad Gita 2.31)

Artinya:

Mengingat tugas dan kewajibanmu sebagai ksatria hendaknya engkau mengetahui bahwa tiada kesibukan yang lebih baik untukmu daripada bertempur berdasarkan prinsip - prinsip dharma; karena itu engkau tidak perlu ragu - ragu.

Yadŗcchayā ca papannai், svrga-dvāram apāvr̦tam, sukhinah kșatriyāh pārtha, labhante yuddham ìdrśsam. (Bhagavad Gita 2.32)

Artinya:

Wahai Partha, berbahagialah para ksatria yang mendapatkan kesempatan untuk bertempur seperti itu tanpa mencarinya - kesempatan yang membuka pintu gerbang planet - planet surga bagi mereka

Atha cet tvam imai் dharmyam, sañgrāmam na karișyasi, tatah sva-dharmai் kīrtim ca hitvā pāpam avāpyasi (Bhagavad Gita 2.33)

Artinya:

Akan tetapi, apabila engkau tidak melaksanakan kewajiban dharma-mu yaitu bertempur, engkau pasti menerima dosa akibat melalaikan kewajibanmu dan dengan demikian kemahsyuranmu sebagai ksatria akan hilang 
Sebagai guru yang paling utama bagi dunia, Sri Krisna menyalahkan sikap Arjuna yang telah berkata "saya tidak menemukan kebaikan apapun dalam pertempuran ini. Pertempuran akan mengakibatkan kita tinggal di neraka untuk selamanya". Pernyataan ini disebabkan oleh kebodohan Arjuna. Arjuna tidak ingin melakukan kekerasan dalam melaksanakan tugasnya. Sedangkan bagi seorang ksatria, berada di medan perang dan tidak melakukan kekerasan adalah filsafat orang bodoh. Dalam Parasara-smrti, atau rumus - rumus dharma hasil karya Parasara, rsi yang mulia ayah dari Vyasadeva dinyatakan:

\section{Ksatriyo hi praja raksan sastra-panih pradandayan nirjitya para-sainyadi ksitim dharmena palayet}

Artinya:

Kewajiban seorang ksatria adalah melindungi para warga negara dari segala jenis kesulitan. Karena alasan itulah ia harus menggunakan kekerasan dalam kasus - kasus yang tepat demi keadilan dan ketertiban. Karena itu, ia harus mengalahkan tentara raja - raja yang iri hati dan dengan demikian berdasarkan prinsip - prinsip dharma ia harus berkuasa di dunia.

Menimbang segala aspek, Arjuna tidak memiliki alasan untuk tidak bertempur. Jika Arjuna mengalahkan musuhnya ia akan menikmati kerajaannya, sedangkan jika kalah ia akan naik ke surga, pintu gerbang surga telah terbuka lebar baginya, pertempuran akan menguntungkan Arjuna dalam kedua keadaan tersebut. Dalam dharma yudha, pejuang secara moral berkewajiban untuk melakukan tugasnya tanpa memikirkan hadiah. Dharma yudha bukan perang agama. Mereka yang terlibat dalam dharma yuddha mempraktikkan tradisi keagamaan yang sama, mengikuti budaya yang sama, mereka memiliki guru yang sama, tinggal di wilayah yang sama, berbicara bahasa yang sama dan memiliki kesamaan etnisitas.

Dharma Yudha tidak melawan orang-orang yang tidak bersalah. Kehidupan perempuan, tawanan perang, dan petani dianggap sakral. Dalam dharma yuddha, pertarungan harus dilakukan dengan sebanding. Prajurit kereta perang tidak seharusnya menyerang kavaleri dan infanteri, mereka yang mengendarai gajah tidak seharusnya menyerang infanteri. Tidak ada yang boleh menyerang musuh yang telah kalah atau menjatuhkan senjata mereka. 


\section{REINTERPRETASI KONSEP DHARMA YUDHA DALAM KONTEKS MODERNISASI DAN DOMINASI AGAMA SEMITIK}

Basis kefilsafatan kajian ini adalah interpretivisme yang bertujuan untuk mengungkap pengetahuan yang bersifat interpretatif dan mencoba untuk memberikan pemahaman (understanding) yang bersifat menyeluruh dan mendalam terhadap objek studi. Sesuai dengan jenis dan basis kefilsafatan kajian ini pendekatan yang dipakai adalah pendekatan hermeneutik. Istilah hermeneutik atau hermeneutika secara etimologis berasal dari kata 'hermeneuin' yang berarti menafsirkan atau seni memberikan makna, seni interpretasi (the art of interpretation). Untuk penafsiran dan pemahaman atas kandungan "isi" teks digunakan pendekatan teori hermeneutik, yaitu ilmu atau keahlian untuk menginterpretasi karya sastra dan ungkapan dalam arti yang lebih luas menurut maksudnya (Susanto, 2016). Hermeneutika pada dasarnya menekankan model penalaran abduksi, yaitu metode yang menjelaskan fakta berdasarkan asumsi-asumsi dan hipotesa mengenai suatu kemungkinan, yang belum merupakan hukum tertentu (Susanto, 2016). Hermeneutik merupakan hasil pemikiran Friederich Schleiermacher (1768-1834), ahli teologi dan juga ahli filologi klasik dari Jerman. Ia berasumsi bahwa jika orang memahami sesuatu, hal ini terjadi dengan analogi, yakni dengan jalan membandingkannya dengan sesuatu yang lain yang sudah diketahuinya. Segala yang diketahui itu membentuk kesatuan-kesatuan yang bersistem atau juga membentuk lingkaran-lingkaran yang terdiri atas bagian-bagian. Lingkaran tersebut sebagai satu keseluruhan menentukan arti masing-masing bagian, dan bagian-bagian itu secara bersamaa-sama membentuk lingkaran (pemahaman). Lingkaran inilah yang disebutnya lingkaran hermeneutik (Susanto, 2016)

Setara Institute mencatat adanya peningkatan kasus pelanggaran kejahatan agama dan kekerasan kepada minoritas, 75 tindakan pelanggaran melibatkan aktor negara, yaitu 71 berbentuk tindakan aktif, 3 tindakan by rule, sementara 1 tindakan lainnya merupakan tindakan pembiaran. Sebanyak 126 tindakan dilakukan oleh aktor non-negara dengan pelaku tertinggi adalah kelompok warga, yakni 28 tindakan (Scholastica Gerintya, 2018). Korban dari tindakan kekerasan ini terutama dialami oleh kelompok minoritas termasuk penganut agama Hindu. Beberapa kasus penghinaan terhadap simbol - simbol agama seringkali menimbulkan polemik, perdebatan bahkan berujung dengan saling hujat dan saling memaki, baik di dunia 
nyata maupun di dunia maya. Mudahnya akses penyebaran informasi melalui media sosial menjadikan masalah ini semakin meruncing. Berita - berita hoax dan ujaran kebencian sangat mudah menjadi viral dan memicu keributan.

Perbedaan cara pandang sering terjadi ketika muncul konflik dan kekerasan sosial yang didalamnya ada aroma agama. Respon orang biasanya terbelah menjadi dua: satu kelompok mengatakan bahwa konflik tersebut adalah konflik agama karena dilakukan oleh komunitas agama, menggunakan spirit agama, bahkan melibatkan simbol - simbol agama. Ayat - ayat suci juga seringkali dijadikan legitimasi dan sarana untuk menumbuhkan rasa permusuhan satu kelompok atas kelompok lainnya. Karena itu konflik seperti ini layak disebut "konflik agama" dan peperangan yang terjadi adalah "perang agama". Sedang kelompok lain mengatakan bahwa konflik tersebut bukan konflik agama. Agama tidak pernah berkonflik, yang ada adalah konflik pemeluk agama (tertentu) yang menjadikan agama sebagai basis solidaritas kelompoknya (Rumadi, 2005).

Konsep perang suci telah diterjemahkan dan dipraktikkan oleh pemeluk agama Semitik dalam sejarah. Oleh karena itu, bisa dipahami jika konsep ini seringkali menjadi inspirasi untuk memusuhi pemeluk agama lainnya. Dorongan demikian menjadikan seseorang merasa sedang berperang melawan kekuatan yang mengancam nilai - nilai sakral dalam agama. Ironisnya, klaim perang suci seringkali melekat dan menjadi inspirasi masing - masing kelompok yang bertikai. Bagaimana mungkin sebuah kekuatan suci berperang melawan kekuatan suci yang lain (Rumadi, 2005).

Seperti yang kita ketahui, dalam konteks Islam, aspek hukum, dan bukan teologi merupakan disiplin yang dominan dalam mendefinisikan dan mengekspresikan keimanan. Sedangkan dalam tradisi kristen, dogma dan doktrin memainkan peranan yang domian dalam mengekspresikan keberagaman dan keyakinan, atau aspek teologi lebih berperan dari hukum. Dalam agama - agama Semitik, kehendak Tuhan terdokumentasikan dalam wahyu dan tradisi kenabian. Orientasi yang berlebihan terhadap aspek legal-formal dan keringnya wacana teologi dalam bangunan keilmuan dan praktek keberagaman inilah yang disinyalir menjauhkan umat - umat agama Semitik mengeksklusifkan diri dan menjauhkan diri dari keberagaman (Rohmanu AR, 2012). 
Dalam agama Hindu, konsep peperangan disebut dengan dharma yudha yang diartikan sebagai peperangan membela dharma. Tuhan memberi manusia potensi dalam bentuk akal dan kesadaran. Kebenaran sebuah agama dapat dilihat dari segi bagaimana pemeluknya mempraktikkannya. Kebenaran agama yang sekedar dilihat dari aspek normatif menjadikan agama tidak mempunyai makna apa - apa bagi kehidupan. Pembacaan terhadap teks tidak bisa melepaskan diri dari nilai - nilai moral dan konteks historis sebuah teks atau pesan.

Pada era kontemporer ini dikenal dengan apa yang disebut "teori fungsional". Teologi dalam pengertian ini tidak dapat dimaknai secara sempit, akan tetapi bagaimana melakukan interpretasi terhadap realitas berdasar perspektif ketuhanan. Teologi dimaknai sebagai kekuatan iman yang bertautan dengan visi sosial yang bersifat emansipatorik. Format teologi fungsional berangkat dari kebutuhan kini, realitas kini dan tantangan - tantangan masa kini, bukan dulu atau nanti (Rohmanu $\mathrm{AR}, 2012)$

Perintah dalam kitab suci untuk berperang mempunyai nilai intrinsiknya sendiri. Sebagai sebuah nilai intrinsik, dharma yudha menggambarkan tentang spirit, etos yang berorientasi pada kebaikan dan kebenaran yang manifestasinya tidak tunggal. Pandangan bahwa hanya dengan berperang seseorang telah melakukan kewajiban agama merupakan pernyataan yang tidak logis. Karena meskipun dalam kondisi tertentu berperang bisa merealisasikan perintah agama, tidak berarti bahwa hanya dengan berperang seseorang bisa melaksanakan perintah agama. Situasi kontemporer yang berbeda sama sekali dengan kondisi sosial budaya ketika teks dharma yudha hadir. Bisa dikatakan bahwa perintah berperang adalah sesuatu yang bersifat normatif dan universal tetapi aplikasi dan bentuk dharma yudha adalah sesuatu yang bersifat praktis dan temporal (Rohmanu AR, 2012)

Berdasarkan konsep teologi fungsional tersebut, maka dharma yudha harus diinterpretasikan kembali sebagai sebuah prinsip. Dalam prinsip ini maka dharma yudha dapat diinterpretasikan:

1. Upaya membela hak-hak dasar kemanusiaan

Agama Hindu sudah mengenal konsep Hak Asasi Manuasia (HAM) sejak zaman dahulu, konsep - konsep hak asasi manusia tertuang dalam ajaran kitab suci Veda baik Veda Sruti maupun Veda Smerti. Hak asasi bukan hanya didapatkan 
manusia saja tetapi seluruh mahluk hidup. Mantera dalam Yajur Veda terjemahan (Puja Gede dkk, 2004) sebagai berikut:

\section{yasmin sarvani bhutanyatmaiva bhutvijanantan tantra ko mohah soka ekavatmanupasyatah (Yajur Veda 40.7)}

Artinya:

Seseorang yang mengangap seluruh umat manusia memiliki atman yang sama dan dapat melihat semua manusia sebagai saudaranya, orang tersebut tidak terikat dalam ikatan dan bebas dari kesedihan.

Kondisi dunia saat ini sesuai fakta memang banyak terjadi kekacauan, perang, penindasan dan lain-lain, yang pada akhirnya menjurus pada pelanggaran HAM. Konsep dari mantram YaJur Veda ini adalah persamaan. Kesalahan terbesar manusia sekarang sering menganggap dirinya berbeda dengan manusia lain hanya karena perbedaan suku, ras dan agama, serta perbedaan kulit. Kita lihat di Indonesia terlihat sikap-sikap intoleransi yang sering dilakukan dengan orang lain yang berbeda paham, yang dibuktikan dengan adanya tindak radikalisme salah satunya kasus-kasus penghinaan agama. Jadi tak heran pada akhirnya berakhir dengan kasus pelanggaran HAM.

Mantram Yajur Veda tersebut mengajarkan bahwa kita adalah sebuah keluarga besar dan membunuh keluarga adalah sebuah dosa besar serta dilarang Hindu. Hindu mengecam segala bentuk pelanggaran hak asasi manusia. Dalam hal ini, atman manusia dikatakan sama karena manusia sebagai wadah bersemayamnya atman dan mempunyai hak, kewajiban dan kedudukan yang sama di mata Ida Sang Hyang Widhi Wasa.

\section{vidya-vinaya-sampanne brahmane gavi hastini suni caiva sva-pake ca panditah sama-darsinah (Bhagavad Gita 2.33)}

Artinya:

Orang bijak melihat dengan pandangan yang sama, baik seorang Brahmana terpelajar dan rendah hati, seekor sapi, seekor gajah, atau bahkan seekor anjing atau seorang yang berkelahiran hina.

Sloka dalam Bhagavad Gita terjemahan (Pudja, 2003) menjelaskan orang yang bijaksana tidak membedakan antara jenis-jenis kehidupan atau kasta-kasta. Seorang 
brahmaṇa dan orang yang dibuang oleh masyarakat barangkali berbeda menurut pandangan masyarakat, atau anjing, sapi, gajah barangkali berbeda ditinjau dari segi jenis kehidupan, tetapi perbedaan badan tersebut tidak berarti menurut sudut pandang seorang rohaniwan yang bijaksana. Ini dilandaskan atas hubungan semua makhluk tersebut dengan Yang Maha Kuasa, sebab Tuhan Yang Maha Esa, bersemayam di dalam hati semua orang melalui bagian yang berkuasa penuh dari Diri-Nya sebagai Paramatma. Pengertian seperti itu tentang Yang Maha Kuasa adalah pengetahuan yang sejati. Berkenaan dengan badan-badan dalam berbagai jenis golongan masyarakat atau jenis-jenis kehidupan, Krishna bermurah hati terhadap semuanya secara merata, sebab Beliau memperlakukan setiap makhluk hidup sebagai kawan. Namun Beliau sendiri tetap sebagai Paramatma, dalam segala keberadaan para makhluk hidup. Krishna sebagai Paramatma bersemayam dalam hati orang buangan dan dalam hati seorang brahmaṇā, walaupun badan brahmaṇā dan badan orang buangan tidak sama. Badan-badan adalah benda-benda material yang dihasilkan dari berbagai sifat material, tetapi sang roh dan roh yang utama dalam badan mempunyai sifat rohani yang sama. Akan tetapi, persamaan sifat antara sang roh dan roh yang utama tidak menyebabkan mereka sejajar dalam jumlah, sebab roh yang individual hanya berada dalam badan ini, sedangkan Paramatma bersemayam dalam setiap badan. Orang yang sadar akan Tuhan mempunyai pengetahuan penuh tentang hal ini; karena itu, dia sungguh-sungguh bijaksana dan mempunyai penglihatan yang merata. Ciri-ciri serupa yang dimiliki oleh sang roh dan roh yang utama ialah bahwa keduaduanya sadar, kekal dan penuh kebahagiaan. Tetapi perbedaannya ialah bahwa sang roh yang individual hanya sadar di dalam lingkungan badan yang terbatas, sedangkan roh yang utama sadar akan semua badan. Roh yang utama bersemayam dalam semua badan tanpa membedakan antara badan-badan itu.

Hindu adalah agama yang universal dan sangat memahami keberagaman mahluk hidup, hal tertulis dalam Upanishad yang mendoakan semua mahluk hidup. (Yayasan Parijata, n.d.)

Ayam bandhurayam neti gananā laghuchetasām, Udāracharitānām tu vasudhaiva kutumbakam (Maha Upanisad 6.72) 
Artinya:

Pemikiran bahwa hanya dialah saudara saya, selain dia bukan saudara saya adalah pemikiran dari orang yang berhati sempit. Bagi mereka yang berwawasan luas, atau orang mulia, mereka mengatakan bahwa seluruh dunia adalah satu keluarga besar.

\author{
Om, Sarve bhavantu sukhinah \\ Sarve santu nirāmayāh \\ Sarve bhadrāṇi paśyantu \\ Mā kashchit duhkha bhägbhavet \\ Om Shāntih, Shāntih, Shāntih
}

(Brihadaranyaka Upanishad 1.4.14)

Artinya:

Semoga semua mahluk makmur dan bahagia

Semoga semua mahluk terbebas dari penyakit

Semoga semua mahluk melihat peningkatan spriritual

Semua semua mahluk tidak menderita

Damai damai damai

Ada beberapa orang yang berpikir sempit bahwa saudara itu memiliki batasan entah itu suku, bangsa ras dan mungkin agama. Pemikiran sempit seperti ini adalah reaksi dari ego, dengan cara berpikir seperti itu maka mereka telah menghilangkan nilai-nilai kemanusiaan yakni cinta kasih terhadap sesama, mereka membatasi diri untuk mencintai semua mahluk hidup.

Beberapa filosof dunia ternama pernah mengatakan bahwa tidak perlu sedarah untuk menjadi keluarga. Para filosof ini menggunakan nurani mereka untuk membangun peradaban walaupun mungkin mereka seorang atheis. Atheis hanya orang yang tidak percaya Tuhan, tapi bukan berarti mereka tidak memiliki nilai kemanusiaan. Jika kita berasal dari sosok yang sama dengan penciptakan kita yakni Tuhan Yang Maha Esa maka sesungguhnya kita semua yang berada di bumi ini adalah saudara sejati.

Bila dikaitkan dengan masa kini, perang suci adalah mempertahankan kebebasan beragama dan melawan pemaksaan dalam agama. Makna ini kemudian diperluas mencakup perlindungan atas komunitas yang ingin menegakkan kebebasan beragama dan hak - hak lainnya. Semangat ini diarahkan untuk melawan tirani. Pandangan tersebut dapat diperluas bahwa dharma yudha harus diarahkan untuk membela harkat kemanusiaan (human dignity). Oleh karena itu tidak salah jika 
pembelaan atas kemanusiaan didasari pada spirit keagamaan. Bahkan agama memang seharusnya diletakkan pada fungsi ini (Rohmanu AR, 2012).

Visi kemanusiaan yang sangat kuat tersebut dapat kita lihat, bukan saja dalam ajaran-ajaran normatif, tidak mendorong umatnya untuk menebar kasih sayang, mengangkat harkat kemanusiaan, mendorong menegakkan keadilan, saling menolong dan menghargai, membantu yang lemah, dan seterusnya. Ajaran-ajaran ideal-normatif yang berdimensi kemanusiaan ini senantiasa dijadikan klaim oleh setiap pemeluk agama bahwa agama mereka mempunyai kepedulian terhadap nasib manusia. Dari sudut ini, sebenarnya tidak ada yang perlu dirisaukan dari perbedaan (institusi) agama.

\section{Bermuatan etis}

Manusia mempunyai otonomi untuk menilai dan menentukan segala tindakannya. Tuhan mengintervensi manusia dalam bentuk pemberian nalar, hati nurani dan kesadaran dan bukan intervensi yang menaifkan otonomi manusia. Agama Semitik menyatakan bahwa Tuhan telah mencatat segala sesuatu dan manusia tinggal menjalankannya. Tentu saja konsep ini jika diartikan secara normatif akan menyesatkan umat beragama. Tuhan bukan pencipta keburukan, bahkan bukan pula pencipta kebaikan, akan tetapi manusia diberi potensi oleh Tuhan dalam bentuk ajal dan kesadaran. Kebaikan merupakan produk dari keputusan kesadaran dan kehendak sebagai manusia. Karena itulah, konsep teologi tersebut idealnya menjadi fondasi bagi pola berpikir umat beragama. Agama yang didasarkan pada teologi yang rasional akan bersifat fungsional bagi kehidupan manusia. Dalam beragama, moral dan etika menjadi instrumen memanusiakan manusia, bukan hanya melayani Tuhan.

Sebuah peradaban tidak bisa dibangun berdasarkan pragmatisme belaka. Setiap peradaban dibangun berdasarkan idealisme dan mimpi. Peradaban tidak bisa dibangun berdasarkan prinsip kekerasan, teorisme dan aktivitas pengerusakan. Dharma Yudha kontemporer hendaknya dibangun di atas fondasi teologi yang bersifat humanis, yakni teologi yang bersifat ramah, lebih berorientasi pada kemaslahatan dan pembangunan peradaban manusia. Dharma yudha tidak boleh dipakai untuk memberangus kemajemukan. Di negara manapun, kemajemukan merupakan sebuah anugerah yang harus dijaga. Karena itu semua agama tidak hanya dituntut untuk bisa memikirkan secara praktis bagaimana bergaul dengan agama lain, akan tetapi didesak 
untuk bisa memahami secara teologis apa makna kehadiran agama - agama dan kepercayaan lain, atau apa makna kemajemukan.

Salah satu kerangka dasar agama Hindu adalah etika. Hal pokok dari etika adalah nilai keindahan dan cinta. Pada umumnya, agama - agama menempatkan cinta sebagai inti terdalam spiritualitasya. Cinta dan keindahan akan membebaskan manusia beragama dari ketakutan dalam beragama (surga - neraka), dan membawanya kedalam tingkat kearifan yang mendalam. Agama yang didasari pada perspektif cinta akan membawa penganutnya pada keluhuran budi. Pada tingkat kematangan religius, agama akan lebih dihayati sebagai komitmen etis dan mistis. Karena ekspresi beragama pada dasarnya adalah kepedulian pada setiap manusia dan seluruh kehidupannya. Bila agama Hindu dihayati pada tingkat seperti ini maka agama ini akan menemukan kembali signifikansinya bagi peradaban saat ini.

Veda sendiri selalu mengungkapkan bahwa tatanan etika atau moralitas merupakan sesuatu yang ultimate dan bersifat imperatif. Hal ini bermakna bahwa prinsip - prinsip etika dan moral merupakan sistem dan struktur dasar bagi bangunan pelayanan kita kepada Tuhan. Manusia sebagai agen pada dasarnya memiliki tugas mencari keindahan Tuhan dan keindahan ciptaan-Nya. Nilai - nilai keindahan itu sendiri merupakan ruh dari moralitas sebagaimana kejujuran, keadilan, kasih sayang dan lainnya yang secara intrinsik bernilai indah.

3. Merealisasikan keadilan sosial

Tidak ada individu atau kelompok yang boleh mengklaim bahwa mereka mempunyai akses secara langsung terhadap kehendak Tuhan. Baik melalui otoritas hukum, atau badan perwakilan rakyat dalam konteks negara modern, masyarakat dituntut untuk mengeimplementasikan keteraturan sosial, yakni keadilan dan kasih sayang. Karena watak dasar manusia yang bisa keliru dan salah maka penterjemahan kehendak Tuhan oleh manusia harus dinilai bersifat fleksibel. Ketika manusia bisa mengimplementasikan keadilan dan kasih sayang maka hal tersebut merupakan cerminan dari kehendak Tuhan. Berdasarkan perspektif tersebut maka Dharma Yudha harus bersubstansikan nilai keadilan dan kasih sayang.

Kesadaran dan kebebasan manusia merupakan ujung tombak keberagaman. Suatu tindakan akan bernilai etis jika didasarkan pada kesadaran individu dan dalam situasi bebas. Dalam wacana etika ini, dikenal dengan istilah otonomi moral. 
Sementara tindakan bagi mereka yang menganut paham subjektivisme moral pada dasarnya tidak pernah bernilai etis, karena etika mengandaikan adanya kesadaran individu, rasionalitas dan buka faktor lain/luar. Inilah yang disebut dengan heteronomi moral, yaitu orang mematuhi perintah bukan karena nilai dan maknanya akan tetapi lebih karena tuntutan ideologi, atau takut dosa atau karena literal teks .

Hukum sebagaimana dikonsepsikan oleh Tuhan tentu bersifat sempurna. Akan tetapi ketika dipahami dan diagensikan oleh manusia ia menjadi tidak sempurna. Oleh karena itu, tidak layak ada klaim - klaim pendapat bahwa pendapat hukum tertentu mewakili kehendak Tuhan. Semua orang mempunyai akses yang sama dan setara untuk menyikap dan melakukan proses pencarian hukum Tuhan. Tuhan tidak menghendaki kebenaran yang bersifat objektif dan tunggal. Tuhan menginginkan hambanya untuk mencari kehendak ilahi. Kebenaran mengikuti upaya pencarian sendiri merupakan kebenaran yang bersifat ultimate. Konsekuensinya, kebenaran diukur berdasarkan ketulusan pencarian individu. Semua dinilai pada proses, sementara hasilnya sepenuhnya Tuhan yang berhak menilainya.

Relevansi Dharma Yudha dengan keadilan sosial bisa bermakna sebagai berikut:

a. Jika seseorang menempati puncak pimpinan atau kekuasaan, Dharma Yudha bermakna melakukan sesuatu secara benar, yakni menjadi bagian dari solusi bukan malah menjadi sumber masalah.

b. Dharma Yudha bagi individu bermakna keberanian untuk menyatakan kebenaran walau di depan penguasa yang tiranik.

c. Bagi ahli agama dan sarjana agama, prinsip Dharma Yudha bermakna tidak menjadikan agama atau otoritas keagamaan untuk kepentingan - kepentingan pribadi atau partisan. Akan tetapi sebaliknya bagaimana ikut mempromosikan kesejahteraan yang lebih luas bagi kehidupan publik.

Hindu mengajarkan umatnya untuk menjaga hubungan antar manusia, Tuhan, dan dunia. Hindu percaya bahwa Tuhan bermanifestasi dalam berbagai aspek kehidupan, baik pada manusia, hewan dan tumbuh - tumbuhan. Dalam filosofi Hindu ada banyak jalan yang dapat dipilih oleh manusia untuk mencapai Tuhan, naik dengan pergi ke tempat ibadah, melakukan japa mantra, melakukan ritual atau melakukan perbuatan amal. Seluruhnya memiliki satu tujuan yaitu Tuhan. Hindu percaya bahwa dari berbagai manifestasi Tuhan umatnya bisa memilih untuk memuja salah satunya. 
Agama adalah hak personal dan umat Hindu harus dapat saling menghargai kebebasan dalam beribadah. Berdasarkan hal tersebut maka Hindu percaya bahwa jika anda seorang Katolik jadilah Katolik yang baik, jika anda Muslin jadilah Muslim yang baik.

Veda menyebutkan istilah "Tat Tvam Asi", yang berarti ia adalah kamu, saya adalah kamu dan semua makhluk adalah sama. Ajaran Tat Tvam Asi adalah ajaran kesusilaan tanpa batas yang identik dengan perikemanusiaan dalam Pancasila. Dalam Upanisad disebutkan sebuah kalimat yang berbunyi "Brahman Atman Aikyam" yang artinya brahman dan atman adalah tunggal. Kesadaran akan tunggalnya jiwatman kita dengan jiwatman orang atau makhluk lain akan menimbulkan kesadaran bahwa kita sebenarnya satu dan sama dengan orang atau makhluk lain. Gus Dur menuliskan bahwa Tuhan tidak perlu dibela, karena Tuhan dapat membela dirinya sendiri (Wahid, 1999). Namun, apakah ketika simbol - simbol agama dan keyakinan kita diinjak injak kita harus diam? Tentu saja tidak. Agama perlu dipertahankan, hanya saja dengan cara dharma. Karena tidaklah tepat jika kita melakukan perbuatan adharma untuk membela dharma.

Di tengah derasnya konflik agama dan modernisasi ada dua agenda yang seiring sejalan perlu digarap. Pertama menghadapi tantangan eksternal berupa budaya kekerasan dan teror, perlu dibangun budaya anti-kekerasan. Kedua, menghadapi tantangan integral berupa gerakan mengikis budaya penuh curiga dan permusuhan. Kedua agenda ini tidak bisa sekedar dibicarakan dalam tataran teori, namun harusnya berwujud dalam bentuk etis-praktis. Upaya teoritis seringkali mandek tanpa hasil, karena itu diperlukan gerakan nyata. Diperlukan upaya - upaya untuk keluar dari penjara eksklusivitas dengan mengatasnamakan sikap, pikiran dan perilaku sebagai mewakili Tuhan. Justru dengan pembentukan identitas diri seperti itulah kita justru menyuburkan kultur kekerasan.

Syarat utama untuk menciptakan perdamaian di dunia adalah kepercayaan yang didasari dengan rasa saling mengerti satu sama lain. Karena itu sangat penting untuk bisa memahami ajaran agama sendiri, dan juga memahami agama lain. Selama manusia tak mampu membebaskan diri dari stereotype negatif agama lain, konflik agama akan terus ada. Apabila umat beragama di negeri ini mampu bergaul dengan baik dengan memperkembangkan tumbuhnya wadah - wadah bersama, wadah - 
wadah interkomunal, maka ini akan menjadi kekuatan yang ampuh untuk meredam setiap konflik agama yang muncul. Kemampuan mengelola konflik agama secara cerdas akan memungkinkan agama - agama di negeri ini untuk memberikan kontribusi sebesar - besarnya bagi pembangunan bangsa Indonesia yang damai dan sejahtera. Ini harusnya menjadi misi bagi semua agama di Indonesia.

\section{SIMPULAN}

Pada masa kini konsep Dharma Yudha tidak lagi dapat diartikan sebagai peperangan dan pertumpahan darah. Konsep membela dharma dalam Dharma Yudha dapat dimaknai kembali sebagai: (1) upaya membela hak - hak dasar manusia, (2) berkehidupan sosial dengan berlandaskan nilai etik dan moral, (3) mewujudkan keadilan sosial bagi seluruh umat manusia.

\section{DAFTAR PUSTAKA}

Asir, A. (2014). Jurnal Penelitian dan Pemikiran Ke Islaman. 1(2355-0104), 50-58.

BBC. (2017). Holy wars. Retrieved from http://www.bbc.co.uk/ethics/ war/religious/holywar.shtml

International, M. R. G. (2018). Minority and Indigenous Trends 2018.

Küng, H. (2005). Religion, violence and "holy wars." International Review of the Red Cross, 87, 253-268.

Pudja, G. (2003). Bhagavd Gita (Pancama Weda). Jakarta: PT Pustaka Mitra Jaya.

Puja Gede dkk. (2004). Yajur Veda (Veda Sruti). Surabaya: Paramita.

Rohmanu AR. (2012). Reinterpretasi jihad: relasi fikih dan akhlak. Ponorogo: Stain PO Press.

Rumadi. (2005). Renungan Santri: Dari jihad hingga kritik wacana agama. Jakarta: Erlangga.

Scholastica Gerintya. (2018). Benarkah Intoleransi Antar-Umat Beragama Meningkat Baca selengkapnya di artikel "Benarkah Intoleransi Antar-Umat Beragama Meningkat?" https://tirto.id/cEPz. Retrieved from https://tirto.id/benarkahintoleransi-antar-umat-beragama-meningkat-cEPz

Susanto, E. (2016). Studi Hermeneutika Kajian Pengantar. Jakarta: Kencana.

Wahid, A. (1999). Tuhan Tidak Perlu Dibela. Yogyakarta: LkiS.

Yayasan Parijata. (n.d.). Upanisad Upanisad Utama. Jakarta: Yayasan Parijata. 